Terra Nova

December 2019, Volume 31, Issue 6, Pages 540-548

https://doi.org/10.1111/ter.12425

https://archimer.ifremer.fr/doc/00512/62348/

\title{
Fluid escape features as relevant players in the enhancement of seafloor stability?
}

\author{
Riboulot Vincent ${ }^{1,{ }^{*}}$, Imbert Patrice ${ }^{2}$, Cattaneo Antonio ${ }^{1}$, Voisset Michel ${ }^{1}$ \\ ${ }^{1}$ IFREMER, REM-GM Plouzané ,France \\ 2 TOTAL, Pau ,France \\ *Corresponding author : Vincent Riboulot, email address : riboulot@ifremer.fr
}

\begin{abstract}
:
Fluid migration within the sedimentary column contributes significantly to slope failure and pockmark formation and can be an effective triggering mechanism to generate submarine landslides. Pockmarks are thus commonly listed among geohazards. Contrary to these accepted notions, we propose here an alternative view of pockmarks with an example from the Eastern Niger Submarine Delta: Pockmarks and associated chimneys may increase or modify the shear strength of sedimentary layers and locally enhance seafloor stability. The analysis of two 3D seismic volumes shows that a landslide deposit divides into two branches around a cluster of three pockmark chimneys, interpreted to impede its further development. The morphological characteristics of a slide constrained by fluid seepage features show the potential role of fluid escape in marine sediment strengthening.
\end{abstract}




\section{INTRODUCTION}

King and MacLean (1970) first defined pockmarks as sub-circular seafloor depressions. Pockmarks, recognized as seafloor expressions of focused fluid flow (Judd and Hovland, 2007), are commonly associated with seismic reflection profiles with a vertical stack of reflection anomalies, for instance changes in amplitude, and positive or negative relief. These anomalies are often referred to as "chimneys" (term used throughout this paper) or "acoustic pipes" (e.g. Løseth et al., 2011). In cold seep systems, chimneys typically form part of the plumbing system and are considered to guide or represent fluids that migrate from a leaking reservoir to the surface (Talukder, 2012). The seismic chimney is a sub-cylindrical fracture cluster that allows vertical fluid migration to by-pass the less permeable sediment (Cartwright et al., 2007; Moss and Cartwright, 2010a, b). Chimneys may correspond to (i) a stack of successive pockmarks, (ii) velocity pull-downs or pull-ups associated with free gas, hydrate and carbonate contents inside active conduits (Hustoft et al., 2007; Hustoft et al., 2010; Moss and Cartwright, 2010a), (iii) an interruption of seismic reflectors due to gas charge (Rao et al., 2001), and/or (iv) deformation of sedimentary layers within a fluid-escape conduit. Their genesis is commonly associated with overpressured fluid (Cartwright et al., 2007; Cartwright and Santamarina, 2015). The occurrence of seismic chimneys has been extensively documented in the Lower Congo Basin (Gay et al., 2006), at the Scotian Shelf (Hovland and Judd, 1988), the Vestnesa Ridge (Petersen et al., 2010), offshore NW-Svalbard (Hustoft et al., 2009), Mauritania (Davies and Clarke, 2010), Norway (Hustoft et al., 2010),

This article is protected by copyright. All rights reserved. 
Namibia (Moss and Cartwright, 2010a, b), Nigeria (Løseth et al., 2011), and in lacustrine environments (Chapron et al., 2004).

Fluid escape could be a triggering mechanism of landslides (Bünz et al., 2005; Chapron et al., 2004); conversely, buried landslides can control the spatial distribution of pockmarks (Riboulot et al., 2013 and refs. therein). A genetic relationship between fluid flow and submarine landslides is supported by the occurrence of pockmarks in the vicinity of submarine landslides (Hovland et al., 2002). Furthermore, the presence of fluid-escape structures and other features suggestive of gas occurrence in the sediment, combined with the existence of a mechanically weak layer, could constitute the main factors controlling instabilities (Lastras et al., 2004). Sediment failure may occur where free and dissolved gas generate excess pore pressure in a transient fluid reservoir due to gas exsolution and expansion (Lafuerza et al., 2012; Riboulot et al., 2013). A decrease in effective stress in the reservoir temporarily transforms it into a weak layer (Locat et al., 2014). Thus, under specific conditions, gas may constitute a major predisposing factor in landslides (e.g. Bünz et al., 2005; Cobbold et al., 2004; Plaza-Faverola et al., 2010; Sun et al., 2012).

The large amount of 2D/3D seismic data and sedimentological observations make the Eastern Niger Submarine Delta (ENSD - Fig. 1) a suitable site to analyze links between marine landslides and fluid seepage (Garziglia et al., 2010; Ker et al., 2010; Riboulot et al., 2012; 2013; Sultan et al., 2011). The detailed analysis of a selected 3D seismic dataset reveals that the relationships between fluid escape and seafloor instability could be more complex than commonly stated and, in particular, that fluid escape could contribute in some way to marine sediment strengthening.

This article is protected by copyright. All rights reserved. 


\section{DATA AND METHODS}

The study area is located $65 \mathrm{~km}$ offshore Nigeria, in water depths ranging from 150 to $800 \mathrm{~m}$ in the ENSD (Fig. 1). The $38 \mathrm{~km}^{2}$ study area is covered by conventional, industrial 3D reflection seismic datasets. The dominant frequencies of the data in the upper $100 \mathrm{~m}$ are 70 $\mathrm{Hz}$ for block 1 and $100 \mathrm{~Hz}$ for block 2 with vertical resolutions of $\sim 10 \mathrm{~m}$ and ca. $7 \mathrm{~m}$ respectively (at a velocity of $1500 \mathrm{~m} \cdot \mathrm{s}^{-1}$ ). Seismic data were interpreted on a workstation using the Total in-house interpretation software Sismage (Guillon and Keskes, 2004). Dip and amplitude seismic attributes were extracted along specific horizons tracked on the seismic cube and presented in Figures 2 to 6: the seafloor (SF), and three horizons related to a submarine landslide named "NG2". The three horizons are the NG2 base (horizon H1), its top (horizon H3) and an internal reflection (horizon H2). (Note: the raw seismic profiles are available in supplementary figures 1 and 2.)

\section{THE SUBMARINE LANDSLIDE NG2}

The NG2 landslide is sandwiched between horizons H1 (base) and H3 (top). H1, the basal shear surface, is continuous beneath NG2, concordant to bedding (Figs. 2). The basal shear surface $\mathrm{H} 1$ dips seaward by about $2.5^{\circ}$. NG2 covers an area of $\sim 17 \mathrm{~km}^{2}$ for an estimated volume of at least $1.5 \mathrm{~km}^{3}$. The source area of NG2 is identified to the north in about 540-m water depth by a prominent headscarp (Fig. 1). Various kinematic indicators identify three sectors with extensional, translational and compressional features (Fig. 2), as observed in other submarine landslides (Bull et al., 2009; Lastras et al., 2002; Martinsen, 1994).

The extensional domain affects an area of $6 \mathrm{~km}^{2}$ and has a marked $15-\mathrm{m}$ high headwall, oriented W-E (Fig. 2A). The arcuate headscarp dips steeply with an inclination of about $30^{\circ}$ (Fig. 5B). Many extensional faults with strike parallel to the headscarp define small This article is protected by copyright. All rights reserved. 
tilted blocks explaining the vertical depletion by sediment stretching (Figs. 2A, 5A and 5B). The translational domain consists of a single translated block covering an area of $2 \mathrm{~km}^{2}$ (Fig. 2A). The seismic facies composed of parallel reflectors is characterized by the same facies as sediment encasing NG2 with the same thickness, about $25 \mathrm{~m}$ (Figs. 2A, 3B and 5D). The compressional domain, covering an area of $9 \mathrm{~km}^{2}$ with an average thickness of $35 \mathrm{~m}$ (Figs. $2 \mathrm{~B}, 5 \mathrm{D})$, is divided into three main zones: two lateral lobes, dominated by pressure ridges (Figs. 2B, 3, 5 and 6), flanking a narrow central zone, where most of the pockmark chimneys occur (Figs. 2C, 3A, 4 and 6). The compressional structures observed in the lateral lobes (Figs. 2B and 3) consist of a succession of parallel thrusts and pop-up blocks in the dip direction, as observed elsewhere (Frey-Martínez et al., 2006; Gafeira et al., 2007; Huvenne et al., 2002). The landslide deposit consists of coherent sediment blocks that have maintained their primary stratification, separated by distinct faults similar to what has been observed for the Storegga slide (Micallef et al., 2007). The restoration of the original geometry of the compressional domain shows this body was $3.5 \mathrm{~km}$ long, while it is now only little more than $2.8 \mathrm{~km}$ long. The shortening of the compressional domain is $20 \%$. The run-out distance of the tilted block (translated domain) is thus limited to $700 \mathrm{~m}$ (restored section in Fig. 7). In the extensional domain, sedimentary deformation and spacing increase downslope and the largest shifting of sediment would be $700 \mathrm{~m}$.

\section{POCKMARKS AND ASSOCIATED CHIMNEYS}

Forty-nine pockmarks $(\mathrm{P})$ reach the seafloor and 23 are buried in the sedimentary column (Fig. 5G). We use here the term Paleo-Pockmark (PP) to address these 23 buried pockmarks. The pockmarks vary in diameter from a few tens of meters to a maximum of 200 $\mathrm{m}$, while the depth of the depression at the seafloor may reach $25 \mathrm{~m}$. All the pockmarks are associated with seismic chimneys. We distinguish (1) the paleo-pockmarks affecting This article is protected by copyright. All rights reserved. 
sedimentary layers well under NG2 (blue in Fig. 5G), (2) those sealed by the NG2 deposit (black in Fig. 5G), (3) pockmarks far from NG2 or crossing through the NG2 deposit (yellow in Fig. 5G), and (4) those located above NG2 probably linked to the occurrence of paleopockmarks sealed by NG2 (red in Fig. 5G). Out of the total of 72 pockmarks and paleopockmarks, only three paleo-pockmarks and the associated chimneys influenced NG2's shape, named PP1, PP2, and PP3 in figures 2 to 6.

The pockmark cluster influencing NG2's shape lies within the central part of the compressional zone of NG2 (Figs. 2, 3 and 5A). Chimneys associated with paleo-pockmarks, PP1, PP2 and PP3, terminate at horizon H3 (red dashed line in Figs. 2C and 4B). Above PP1, PP2 and PP3, the destabilized body NG2 is thinner and the acoustic facies is different: no internal structure or bedding - transparent acoustic facies probably associated with reworked sediments (Fig. 3B). These chimneys are $200 \mathrm{~m}$ high and are rooted in a large paleo-channel, similar to that shown by Gay et al. (2003) in the Lower Congo basin. The portion of the chimney included in the stratigraphic interval affected by NG2 is not reworked by the landslide (Figs. 2C, 3A and 4). Pockmarks P1, P2 and P3 have diameters of 140, 150 and 90 $\mathrm{m}$ and depths of 30,25 and $19 \mathrm{~m}$, respectively. They are located right above the flanks of the paleo-pockmarks described previously and are associated with chimneys rooted in sedimentary layers above the NG2 deposit (example of P1 in Fig. 4). There is no seismically visible link between the two features, which are separated by the NG2 deposits and others hemipelagic layers.

\section{INTERPRETATION OF LANDSLIDE-POCKMARK CHIMNEY INTERACTION}

The geomorphological analysis of NG2 suggests that the translational domain constituted by one intact block was tilted and translated from the north to the south over 700 $\mathrm{m}$, inducing compression of the downdip slope. The landslide deposit is buttressed downdip This article is protected by copyright. All rights reserved. 
against stratigraphically equivalent undisturbed strata. Following the classification of FreyMartínez et al. (2006), the lateral lobes of NG2 may be interpreted as a frontally confined landslide. The central zone of the NG2 compressional deposit corresponds to the area where we observed the seismic chimneys associated with PP1, PP2 and PP3. It has a more complex morphology than the lateral lobes. Updip of the pockmarks, the frontal zone is dominated by pressure ridges and thrusts detached over the basal shear surface (Figs. 2 and 6). The basal shear surface ramps up just updip of the pockmarks, separating deformed strata updip from undeformed strata downdip. Downdip of the pockmarks, a thin, disturbed frontal layer of NG2, composed of the most reworked sediment (Figs. 3B and 5B), overlies the autochthonous equivalent of the section remobilized by NG2. This NG2 frontal deposit shows dominantly transparent seismic facies with a relatively smooth top. In addition to the pressure ridges identified in the lateral lobes, a secondary fabric of ridges is located around the PP1 chimney interpreted as a sedimentary rotation around this chimney (Fig. 6). The central zone is not affected by deformation downdip of the PP2 and PP3 chimneys. The sediment unit that includes the chimneys has the same stratification and thickness as the series out of NG2 (Fig. 2B). The NG2 deposit in the central zone thus corresponds to autochthonous sediments covered by a frontally emergent landslide (Fig. 5B). The compressed sedimentary mass ramps up from the original level of the basal shear surface onto the seafloor updip of the pockmark chimneys.

The location of the three pockmarks P1, P2, and P3, over the flanks of paleopockmarks, PP1, PP2 and PP3, are unlikely to be a coincidence. The chimneys associated with the paleo-pockmarks form a highly permeable zone, analogous to that known as a "seal bypass system" (Cartwright et al., 2007), where fluids and gas can be transported faster than would otherwise be allowed by normal permeability levels in the sediment pore network (Riboulot et al., 2014). These chimneys may represent a vertical stack of successive paleo- 
pockmarks that drained fluids to the surface before NG2 was emplaced, and reactivated after NG2.

\section{WHY POCKMARKS STABILIZE SEDIMENT}

The spatial relationship observed between the frontally emergent slide domain of NG2 and the pockmark chimneys associated with PP1, PP2 and PP3 indicates that chimneys may prevent local sliding (Fig. 7). The steepening of the basal shear surface to form up-stepping ramps updip of pockmark chimneys suggests their influence as mechanical asperities. A localized variation of the mechanical properties of the material hampers sediment destabilization, as previously mentioned by Frey Martinez et al. (2005). The possible cause of local higher mechanical resistance is chimneys forcing the establishment of ramps. We propose two viable but not mutually exclusive explanations for considering higher mechanical resistance along chimneys.

(1) Chimneys could be cemented by carbonate precipitation, as has been observed for other chimneys, thus enhancing the mechanical properties of the sediment. Indeed, outcrop observations in a number of sedimentary basins have shown tubular carbonate pipes underneath fluid venting features (Aiello et al., 2001; Gay et al., 2007; Nyman et al., 2010; Nyman et al., 2006). Spectacular examples are discovered in the region of Pobiti Kamani near Varna in Bulgaria: methane-derived carbonate columns reaching $10 \mathrm{~m}$ in height and 1.5 $m$ in diameter. They are interpreted by De Boever et al. (2009) as the fossil expression of a former gas plume that was percolated up through the host rock. Observations made worldwide on seismic data show that chimneys are dominated by pull-up effects associated with a high-velocity material when there are carbonate precipitates along gas migrating ways

(Hustoft et al., 2007). However, in the study area, the seismic signatures of the chimneys do not show the presence of high amplitude reflectors and velocity pull-up effects. This This article is protected by copyright. All rights reserved. 
interpretation could still be valid only with the assumption that (1) the carbonate precipitates within the chimney are unequally distributed and discontinuous, (2) the induration of sediment increases the mechanical resistance without greatly increasing the velocity and causing seismic anomaly, or (3) the chimney sizes are under the threshold of detection of the seismic system.

(2) The basal shear surface, locus of an existing surface of lower resistance or a surface where there is a reduction in shearing resistance (Locat et al., 2014), was not present in the areas of fluid migrating features. The pockmark chimneys allowed fluids from the basal shear surface to propagate to the surface, meaning that the sedimentary layer forming the basal shear surface has lost fluid in the areas "drained" by the chimneys and pockmarks (Fig. 6). Hence, the basal shear surface would gain higher frictional resistance close to the chimneys because of the consolidation effect, and hence the slide could not propagate further downdip. Sliding would then have been blocked where the weak layer was absent.

\section{CONCLUSION}

Based on a 3D seismic dataset from the Gulf of Guinea, we present a newly discovered geometry of the frontal deposit of a landslide named NG2 deflected around a cluster of pockmarks and their associated chimneys. The analysis of 3D seismic data allows to describe, with specific details, the geomorphological link between fluid seepage features and slope failure. The two lateral branches of the NG2 frontal deposit and their pressure ridges deflected around the pockmark stacks. This indicates that chimneys can act as an obstacle to landslide advancement. The pockmarks and their associated chimneys seem to play the role of distal buttresses to the sliding and are filled by the frontal emergent part of the landslide.

This article is protected by copyright. All rights reserved. 
This work provides original observations suggesting that active pockmarks may locally enhance seafloor stability in continental margins by draining potential decollement layers and reducing excess pore pressure and/or strengthening the sedimentary cover due to authigenic carbonate precipitation along the associated plumbing system.

\section{ACKNOWLEDGMENTS}

This work was developed and funded by IFREMER and Total through the ERIG3D project. The identification of the nature of the pockmarks and mapping of NG2 would have been impossible without the use of reprocessed exploration 3D seismic data kindly provided by Total and Total Nigeria E\&P. The authors acknowledge the fruitful and constructive English editing advices and corrections by Alison Chalm. We are also grateful to the Editors, M. Coleman and J. Peckmann and the reviewers, A. Plaza-Faverola, C. Huebscher and one anonymous for their insightful comments and corrections which have significantly improved this paper.

\section{DATA AVAILABILITY}

The data that support the findings of this study are available from the corresponding author upon reasonable request. The data are not publicly available due to privacy restrictions.

This article is protected by copyright. All rights reserved. 


\section{FIGURE LEGENDS}

Figure 1: Block diagram of the study area showing seafloor bathymetry (horizontal resolution: $25 \mathrm{~m}$ ), horizon $\mathrm{H} 3$ (top of the NG2 landslide) and oil industry 3D seismic data. The NG2 landslide shows an extensional domain with an arcuate geometry of the headscarp and the compressional domain with pressure ridges. Red lines show the location of the seismic lines extracted from the 3D seismic data presented in Figures 2 and 3.

Figure 2: Cross-section architecture of NG2 from 3D seismic data. A: N-S seismic line showing the three physiographic domains. The extensional domain is dominated by the normal fault and graben. The translated block maintains the original stratification similar to that of the host sediment. B: Close-up view of the frontal deposit of the compressional domain dominated by pop-up and thrusted blocks. The preserved stratification of the blocks is the key to reconstructing the original geometry of the layers and calculating the shortening rate. The compressional domain is $2.75 \mathrm{~km}$ long and represents a $20 \%$ shortening of the reconstructed 3.5-km long pre-landslide deposit. C. N-S seismic line through landslide NG2 where the sedimentary layers are disturbed by fluid-escape features named the paleopockmarks PP1 and PP2. The primary stratification around the two chimneys associated with PP1 and PP2 is not affected by the landslide and constitutes a buttress for the frontal deposit of the landslide. The ramps are located 100 to $200 \mathrm{~m}$ updip the paleo-pockmarks.

Figure 3: A: W-E seismic line through the frontal deposit of NG2 and two pockmarks P2 and P3. The seismic facies of the landslide deposit is chaotic and constituted by thrusted blocks but above the paleo-pockmarks PP2 and PP3, it is transparent. B: Four images, taken along inline seismic profiles, from sediment inside and outside NG2 show the reworking state of the sedimentary layers. The frontally confined slide is less deformed than the frontally emergent slide which spreads above the paleo-pockmarks.

This article is protected by copyright. All rights reserved. 
Figure 4: Close-up view of figure $2 \mathrm{C}$ focused on pockmark P1. It presents the raw seismic profile and its interpretation to highlight the relative chronology of events. The seismic data show the chimney associated with the paleo-pockmark PP1 appeared before the slide NG2.

Figure 5: NG2 landslide characteristics and pockmark location. A: Dip map of the basal shear surface (Horizon H1 in Fig. 2) of NG2. Chimneys associated with the paleopockmarks PP1, PP2 and PP3 are located in the central part of NG2. B: Dip map of the top of NG2 showing the headwall and the toe domains. C: Bathymetric map with overlain dip map of the seafloor. D: Isopach map of the H3-H1 interval (converted to meters using a velocity of $1500 \mathrm{~m} . \mathrm{s}^{-1}$ ), showing the headscarp, the translated block (same thickness as the undisturbed sediment) and the frontal deposit. E: Summary of the morphological characteristics of NG2 and the pockmarks.

Figure 6: Characteristics of the compressional domain of NG2 landslide. A: Dip and B: Amplitude maps of horizon $\mathrm{H} 2$ showing the pressure ridge re-orientation around the chimneys and the size of unaffected areas around the chimneys, a few hundreds of meters in diameter in this setting. This is much higher than the size of carbonate cemented chimneys seen elsewhere. These maps highlight a zone between the two chimneys not affected by the sliding. This observation supports the hypothesis that the chimneys have drained all this area preventing the sliding. C: Restored bathymetric profile of the basal shear surface throughout the compressional domain. The updip part of the compressional domain is characterized by a higher slope angle $\left(1.8^{\circ}\right)$ than the downdip part (close to 0 ). It shows the sliding stopped when this angle fall significantly.

Figure 7: Schematic model for the emplacement of NG2. A, B: The part of NG2 disturbed by pockmarks and associated chimneys can be characterized as a frontally emergent landslide. The chimneys strengthen the sedimentary layers hampering destabilization of the 
downdip part. The sedimentary mass is buttressed against the frontal ramp and jumps up above the original basal shear surface where it was affected by fluid seepages. The morphology of NG2 is a combination of frontally confined and frontally emerged landslide behavior, modified by the effect of chimneys.

\section{REFERENCES}

Aiello, I. W., Garrison, R. E., Moore, J. C., Kastner, M., and Stakes, D. S. (2001). Anatomy and origin of carbonate structures in a Miocene cold-seep field. Geology, 29(12), 1111-1114.

Bull, S., Cartwright, J., and Huuse, M. (2009). A review of kinematic indicators from masstransport complexes using 3D seismic data. Marine and Petroleum Geology, 26(7), 1132-1151.

Bünz, S., Mienert, J., Bryn, P., and Berg, K. (2005). Fluid flow impact on slope failure from 3D seismic data: a case study in the Storegga Slide. Basin Research, 17(1), 109-122.

Bünz, S., Mienert, J., Vanneste, M., and Andreassen, K. (2005). Gas hydrates at the Storegga Slide: Constraints from an analysis of multicomponent, wide-angle seismic data. Geophysics, 70(5), B19-B34.

Cartwright, J., Huuse, M., and Aplin, A. (2007). Seal bypass systems. AAPG bulletin, 91(8), 1141-1166.

Cartwright, J., and Santamarina, C. (2015). Seismic characteristics of fluid escape pipes in sedimentary basins: implications for pipe genesis. Marine and Petroleum Geology, 65, 126-140.

Chapron, E., Van Rensbergen, P., De Batist, M., Beck, C., and Henriet, J. P. (2004). Fluid-escape features as a precursor of a large sublacustrine sediment slide in Lake Le Bourget, NW Alps, France. Terra Nova, 16(5), 305-311.

Cobbold, P.R., Mourgues, R., and Boyd, K., (2004). Mechanism of thin-skinned detachment in the Amazon Fan: assessing the importance of fluid overpressure and hydrocarbon generation. Marine and petroleum geology, 21, 1013-1025.

Davies, R. J., and Clarke, A. L. (2010). Methane recycling between hydrate and critically pressured stratigraphic traps, offshore Mauritania. Geology, 38(11), 963-966.

De Boever, E., Huysmans, M., Muchez, P., Dimitrov, L., and Swennen, R. (2009). Controlling factors on the morphology and spatial distribution of methane-related tubular concretions-Case study of an Early Eocene seep system. Marine and Petroleum Geology, 26(8), 1580-1591.

Frey Martinez, J., Cartwright, J., and Hall, B. (2005). 3D seismic interpretation of slump complexes: examples from the continental margin of Israel. Basin Research, 17(1), 83-108.

Frey-Martínez, J., Cartwright, J., and James, D. (2006). Frontally confined versus frontally emergent submarine landslides: a 3D seismic characterisation. Marine and Petroleum Geology, 23(5), 585-604.

Gafeira, J., Bulat, J., and Evans, D. (2007). The southern flank of the Storegga Slide: imaging and geomorphological analyses using 3D seismic. In Submarine Mass Movements and Their Consequences (pp. 57-65): Springer.

This article is protected by copyright. All rights reserved. 
Garziglia, S., Sultan, N., Cattaneo, A., Ker, S., Marsset, B., Riboulot, V., Voisset, M., Adamy, J., and Unterseh, S., (2010). Identification of shear zones and their causal mechanisms using a combination of cone penetration tests and seismic data in the Eastern Niger Delta, In Submarine Mass Movements and Their Consequences (pp. 5565): Springer.

Gay, A., Lopez, M., Berndt, C., and Seranne, M. (2007). Geological controls on focused fluid flow associated with seafloor seeps in the Lower Congo Basin. Marine Geology, 244(1), 68-92.

Gay, A., Lopez, M., Cochonat, P., Sultan, N., Cauquil, E., and Brigaud, F. (2003). Sinuous pockmark belt as indicator of a shallow buried turbiditic channel on the lower slope of the Congo Basin, West African Margin. Geological Society, London, Special Publications, 216(1), 173-189.

Gay, A., Lopez, M., Ondreas, H., Charlou, J. L., Sermondadaz, G., and Cochonat, P. (2006). Seafloor facies related to upward methane flux within a Giant Pockmark of the Lower Congo Basin. Marine Geology, 226(1), 81-95.

Guillon, S., and Keskes, N. (2004, 2004). Sismage and the 3D Visualization at Total. Paper presented at the AAPG International Conference, Cancun, Mexico.

Hovland, M., Gardner, J. V., and Judd, A. G. (2002). The significance of pockmarks to understanding fluid flow processes and geohazards. Geofluids, 2(2), 127-136.

Hovland, M., and Judd, A. G. (1988). Seabed pockmarks and seepages: Impact on geology, biology and the marine environment: London. Graham and Trotman, 293.

Hustoft, S., Bünz, S., and Mienert, J. (2010). Three-dimensional seismic analysis of the morphology and spatial distribution of chimneys beneath the Nyegga pockmark field, offshore mid-Norway. Basin Research, 22(4), 465-480.

Hustoft, S., Bünz, S., Mienert, J., and Chand, S. (2009). Gas hydrate reservoir and active methane-venting province in sediments on $<20$ Ma young oceanic crust in the Fram Strait, offshore NW-Svalbard. Earth and Planetary Science Letters, 284(1), 12-24.

Hustoft, S., Mienert, J., Bünz, S., and Nouzé, H. (2007). High-resolution 3D-seismic data indicate focussed fluid migration pathways above polygonal fault systems of the midNorwegian margin. Marine Geology, 245(1), 89-106.

Huvenne, V. A. I., Croker, P. F., and Henriet, J. P. (2002). A refreshing 3D view of an ancient sediment collapse and slope failure. Terra Nova, 14(1), 33-40.

Judd, A., and Hovland, M. (2007). Seabed fluid flow. The impact on geology, biology and the marine environment. Cambridge University, Cambridge.

Ker, S., Marsset, B., Garziglia, S., Le Gonidec, Y., Gibert, D., Voisset, M., and Adamy, J., (2010). High-resolution seismic imaging in deep sea from a joint deep-towed/OBH reflection experiment: application to a Mass Transport Complex offshore Nigeria. Geophysical Journal International, 182, 1524-1542.

King, L. H., and MacLean, B. (1970). Pockmarks on the Scotian shelf. Geological Society of America Bulletin, 81(10), 3141-3148.

Lafuerza, S., Sultan, N., Canals, M., Lastras, G., Cattaneo, A., Frigola, J., Costa, S., and Berndt, C. (2012). Failure mechanisms of Ana Slide from geotechnical evidence, Eivissa Channel, Western Mediterranean Sea. Marine Geology, 307, 1-21.

Lastras, G., Canals, M., Hughes-Clarke, J. E., Moreno, A., De Batist, M., Masson, D. G., and Cochonat, P. (2002). Seafloor imagery from the BIG'95 debris flow, western Mediterranean. Geology, 30(10), 871-874.

Lastras, G., Canals, M., Urgeles, R., Hughes-Clarke, J. E., and Acosta, J. (2004). Shallow slides and pockmark swarms in the Eivissa Channel, western Mediterranean Sea. Sedimentology, 51(4), 837-850.

This article is protected by copyright. All rights reserved. 
Locat, J., Leroueil, S., Locat, A., and Lee, H. (2014). Weak Layers: Their Definition and Classification from a Geotechnical Perspective. In Submarine Mass Movements and Their Consequences (pp. 3-12): Springer.

Løseth, H., Wensaas, L., Arntsen, B., Hanken, N.-M., Basire, C., and Graue, K. (2011). 1000 $\mathrm{m}$ long gas blow-out pipes. Marine and Petroleum Geology, 28(5), 1047-1060.

Martinsen, O. (1994). Mass movements. In The geological deformation of sediments (pp. 127-165): Springer.

Micallef, A., Masson, D. G., Berndt, C., and Stow, D. A. V. (2007). Morphology and mechanics of submarine spreading: a case study from the Storegga Slide. Journal of Geophysical Research: Earth Surface (2003-2012), 112(F3).

Moss, J. L., and Cartwright, J. (2010a). 3D seismic expression of km-scale fluid escape pipes from offshore Namibia. Basin Research, 22(4), 481-501.

Moss, J. L., and Cartwright, J. (2010b). The spatial and temporal distribution of pipe formation, offshore Namibia. Marine and Petroleum Geology, 27(6), 1216-1234.

Nyman, S. L., Nelson, C. S., and Campbell, K. A. (2010). Miocene tubular concretions in East Coast Basin, New Zealand: Analogue for the subsurface plumbing of cold seeps. Marine Geology, 272(1), 319-336.

Nyman, S. L., Nelson, C. S., Campbell, K. A., Schellenberg, F., Pearson, M. J., Kamp, P. J. J., Browne, G.H., and King, P. R. (2006). Tubular carbonate concretions as hydrocarbon migration pathways? Examples from North Island, New Zealand.

Petersen, C. J., Bünz, S., Hustoft, S., Mienert, J., and Klaeschen, D. (2010). High-resolution P-Cable 3D seismic imaging of gas chimney structures in gas hydrated sediments of an Arctic sediment drift. Marine and Petroleum Geology, 27(9), 1981-1994.

Plaza-Faverola, A., Bünz, S., and Mienert, J. (2010). Fluid distributions inferred from P-wave velocity and reflection seismic amplitude anomalies beneath the Nyegga pockmark field of the mid-Norwegian margin. Marine and Petroleum Geology, 27(1), 46-60.

Rao, Y., Subrahmanyam, C., Rastogi, A., and Deka, B. (2001). Anomalous seismic reflections related to gas/gas hydrate occurrences along the western continental margin of India. Geo-Marine Letters, 21(1), 1-8.

Riboulot, V., Cattaneo, A., Berné, S., Schneider, R. R., Voisset, M., Imbert, P., and Grimaud, S. (2012). Geometry and chronology of late Quaternary depositional sequences in the Eastern Niger Submarine Delta. Marine Geology, 319, 1-20.

Riboulot, V., Cattaneo, A., Sultan, N., Garziglia, S., Ker, S., Imbert, P., and Voisset, M. (2013). Sea-level change and free gas occurrence influencing a submarine landslide and pockmark formation and distribution in deepwater Nigeria. Earth and Planetary Science Letters, 375, 78-91.

Riboulot, V., Thomas, Y., Berné, S., Jouet, G., and Cattaneo, A. (2014). Control of Quaternary sea-level changes on gas seeps. Geophysical Research Letters, 41(14), 4970-4977.

Sultan, N., Riboulot, V., Ker, S., Marsset, B., Geli, L., Tary, J.-B., Klingelhoefer, F., Voisset, M., Lanfumey, V., and Colliat, J.-L. (2011). Dynamics of fault-fluid-hydrate system around a shale-cored anticline in deepwater Nigeria. Journal of Geophysical Research: Solid Earth (1978-2012), 116(B12).

Sun, Q., Wu, S., Cartwright, J., and Dong, D. (2012). Shallow gas and focused fluid flow systems in the Pearl River Mouth Basin, northern South China Sea. Marine Geology, 315, 1-14.

Talukder, A. R. (2012). Review of submarine cold seep plumbing systems: leakage to seepage and venting. Terra Nova, 24(4), 255-272.

This article is protected by copyright. All rights reserved. 


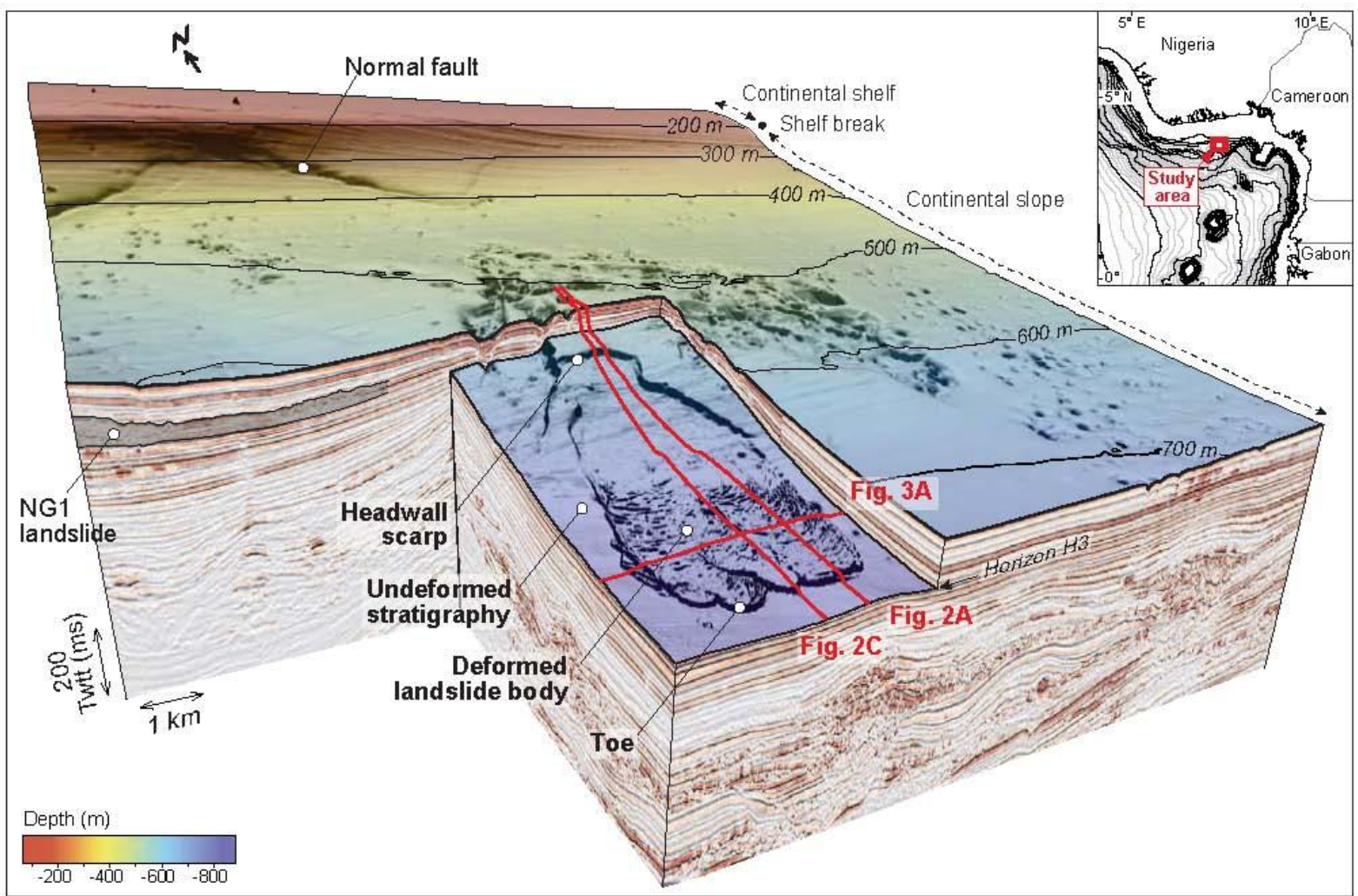

This article is protected by copyright. All rights reserved. 

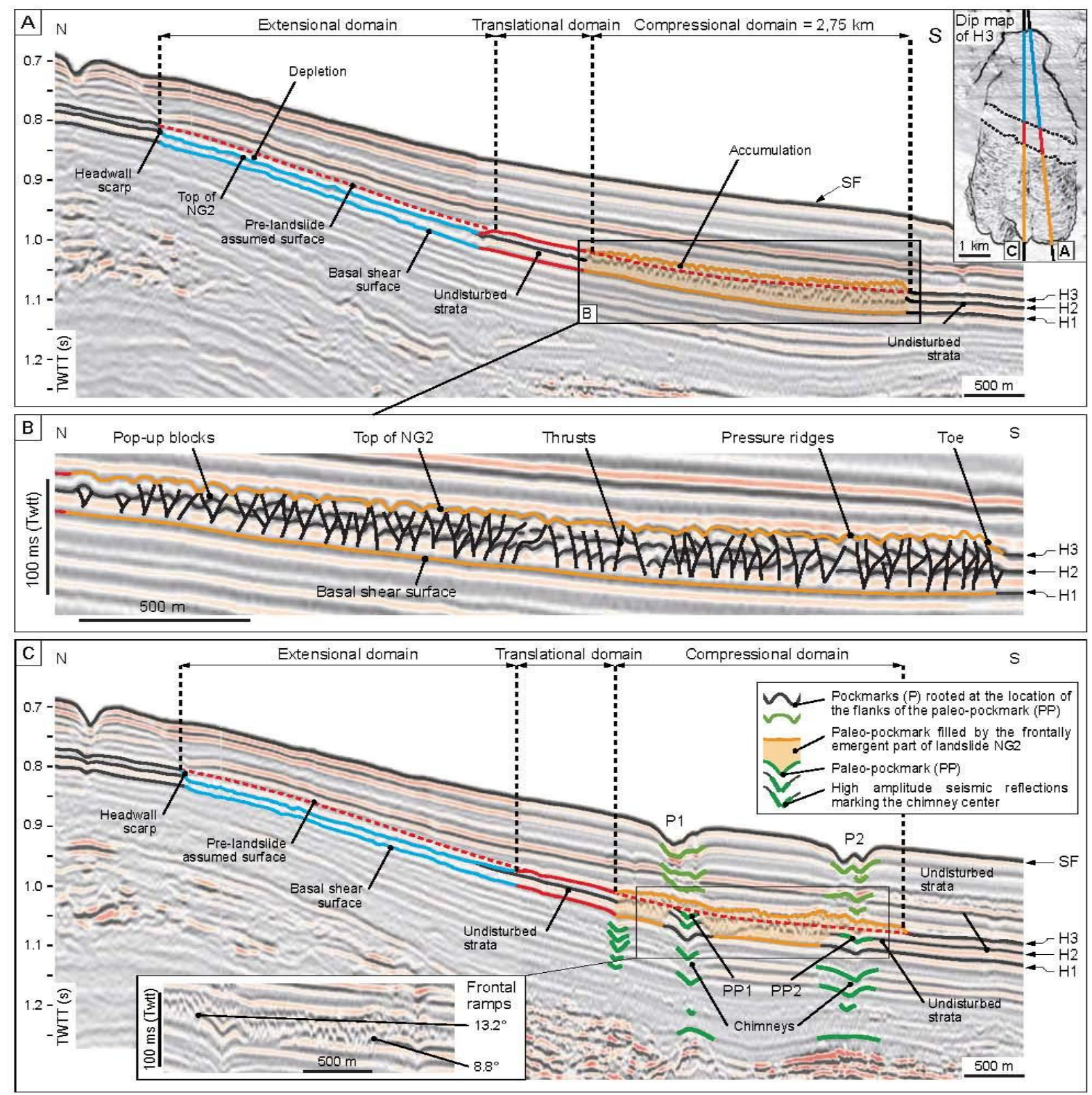

This article is protected by copyright. All rights reserved. 


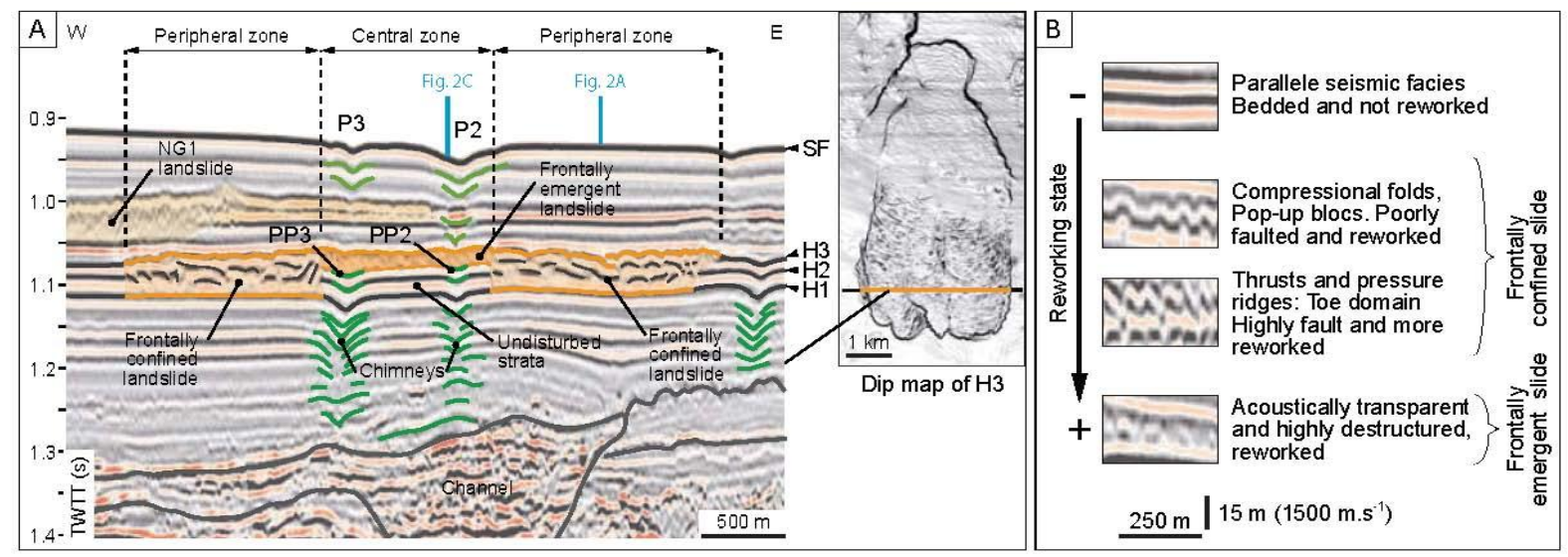

This article is protected by copyright. All rights reserved. 

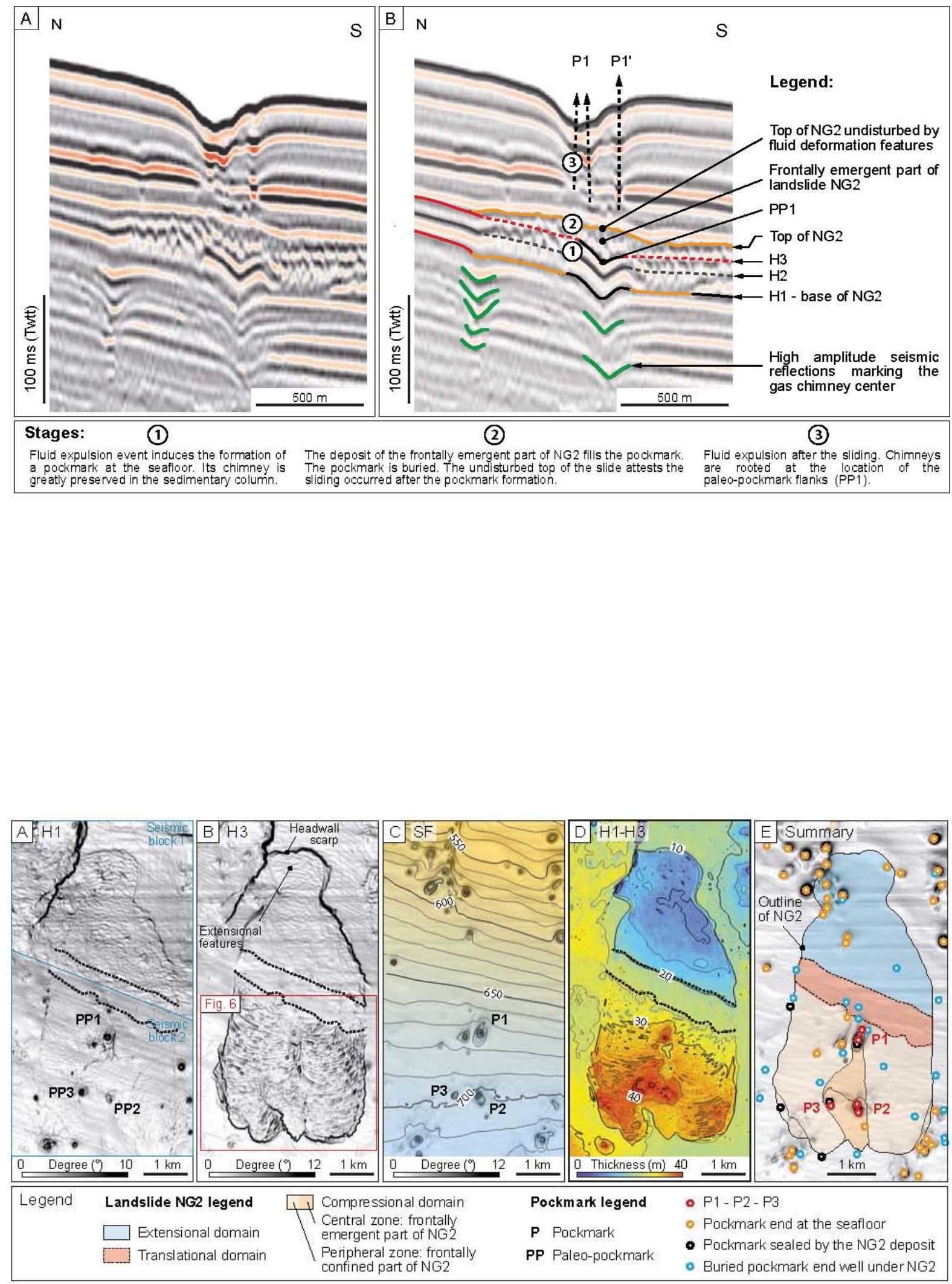

This article is protected by copyright. All rights reserved. 


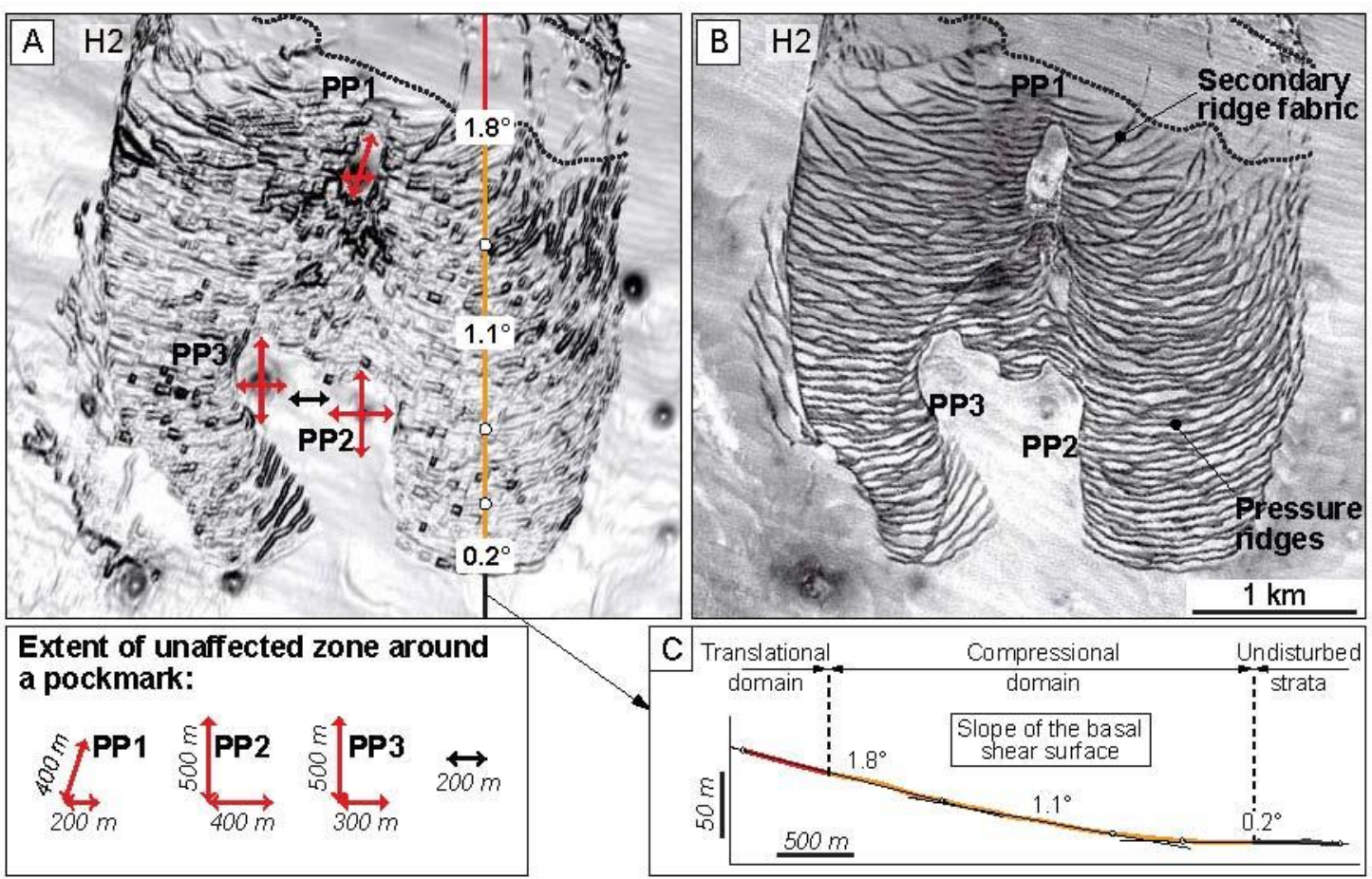

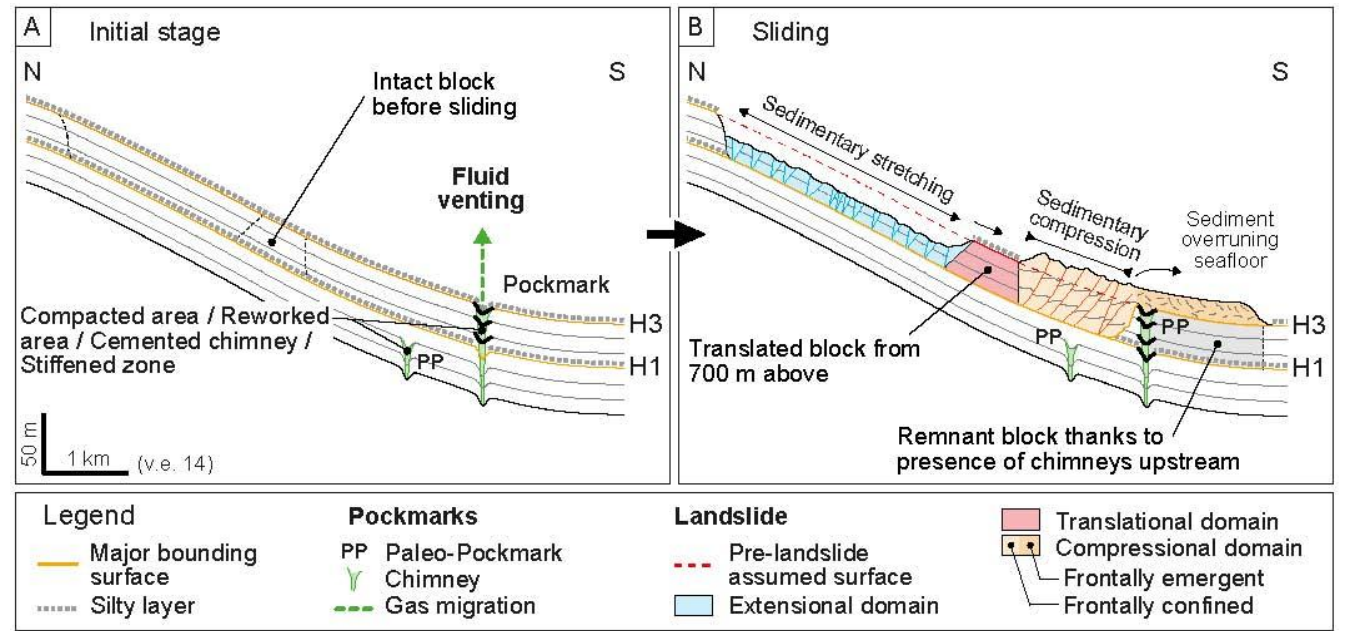

This article is protected by copyright. All rights reserved. 